\title{
DAMPAK PEMBANGUNAN INDUSTRI PARIWISATA TERHADAP ALIH FUNGSI LAHAN \\ (Studi Tentang Kehidupan Sosial Budaya Masyarakat Desa Teluk Bakau, Kecamatan Gunung Kijang, Kabupaten Bintan, Kepulauan Riau)
}

\author{
Miswanto $^{1}{ }^{2}$, Mat Safaat ${ }^{3}$
}

\begin{abstract}
Riau Islands as one of the tourism destinations in Indonesia that has unique tourist uniqueness. The uniqueness and potential of tourism in the Riau Islands is developed as one of the tourism destinations based on culture and supported by the beauty of nature is very interesting. The emergence of maritime tourism as the most popular place impacts the tourism in the Riau Islands region. Many changes occur due to the development of tourism. However, the most attention is the high level of tourism accommodation development with a very limited amount of land. The limitation does not necessarily stop development and even leads to a higher level of functional alteration that threatens the existence of green open spaces that also impact to other areas as happened in Teluk Village Mangrove, Gunung Kijang District. Besides that, the lack of human resources, especially in Teluk Bakau Village, Gunung Kijang Subdistrict, is still not able to compete in tourism sector either in local, national or international scale. If this is left is not impossible that tourism was originally expected to be able to improve the welfare of society it will threaten the welfare of the community itself. Intangible is seen there is movements of people who are now tend to orient towards profit financially or profit oriented. Because, tourism industry is seen as a profitable activity and able to bring in great revenue. But, reality in the field shows that the development of Touris $m$ Village has not been side with the community of Teluk Bakau Village. As the development of coastal tourism is a tourism asset sold for tourist satisfaction. However, the development of tourist villages is not aligned with people's lives. The socio-economic life of the Bakau Bay community is unchanged while investors reap huge profits from this touris m activity. In fact, if there is no coastal tourism industry tourism in Teluk Bakau Village will not grow.
\end{abstract}

Keywords: Development, Tourism, Land Function Transfer

\begin{abstract}
Abstrak
Kepulauan Riau sebagai salah satu destinasi pariwisata di Indonesia yang memiliki keunikan wisata yang khas. Keunikan dan potensi pariwisata yang ada di Kepulauan Riau yang dikembangkan sebagai salah satu destinasi pariwisata berbasiskan pada budaya serta ditunjang oleh keindahan alam yang sangat menarik. Munculnya wisata bahari sebagai tempat yang paling diminati berdampak kepada kepariwisataan di daerah Kepulauan Riau. Banyak perubahan terjadi akibat dari perkembangan pariwisata. Namun yang paling menarik perhatian adalah tingginya tingkat
\end{abstract}

\footnotetext{
${ }^{1}$ Dosen Jurusan Ilmu Sosiologi, STISIPOL Raja Haji, Tanjung Pinang, Kepulauan Riau

${ }^{2}$ Korespondensi Penulis, email: miswanto0584@gmail.com

${ }^{3}$ Mahasiswa Jurusan IImu Sosiologi, STISIPOL Raja Haji Tanjung Pinang, Kepulauan Riau.

DOI: 10.25077/jantro.v20.n1.p45-55.2018

JANTRO ISSN: 2355-5963 (Online)

under Lisensi Creative Commons Atribusi-BerbagiSerupa 4.0 Internasional
} 
pembangunan usaha akomodasi pariwisata dengan jumlah lahan yang sangat terbatas. Keterbatasan tersebut tidak serta merta menghentikan pembangunan bahkan mengakibatkan semakin tingginya tingkat alih fungsi yang mengancam eksistensi ruang terbuka hijau yang juga berimbas ke daerah lain sebagai mana yang terjadi di Desa Teluk Bakau, Kecamatan Gunung Kijang. Disamping itu juga, minimnya sumber daya manusia yang ada khususnya di Desa Teluk Bakau, Kecamatan Gunung Kijang, masih belum mampu bersaing dalam sektor pariwisata baik dalam skala lokal, Nasional maupun Internasional. J ika hal ini dibiarkan bukan tidak mungkin pariwisata yang awalnya diharapkan mampu untuk meningkatkan kesejahteraan masyarakat justru akan mengancam kesejahteraan masyarakat itu sendiri. Secara intangible terlihat ada sebuah pergerakan dari masyarakat yang kini cenderung berorientasi kearah keuntungan secara finansial atau profit oriented. Karena, Industri pariwisata dipandang sebagai kegiatan yang menguntungkan dan mampu mendatangkan pendapatan yang besar. namun, kenyataan di lapangan menunjukkan bahwa pengembangan Desa Wisata belum berpihak kepada masyarakat Desa Teluk Bakau. Seperti pembangunan pariwisata yang mengarah ke pinggir pantai merupakan aset pariwisata yang dijual untuk kepuasan wisatawan. Namun, pengembangan desa wisata tidak berpihak kepada kehidupan Masyarakat. Kehidupan Sosial-ekonomi masyarakat Desa Teluk Bakau tidak mengalami perubahan sementara investor meraup keuntungan besar dari aktivitas pariwisata ini. Padahal, jika tidak ada lahan pinggir pantai industri pariwisata di Desa Teluk bakau tidak akan berkembang.

Kata kunci : Pembangunan, Pariwisata, Alih Fungsi Lahan

\section{A. PENDAhULUAN}

$\mathrm{P}$ ada hakekatnya, pembangunan adalah proses perubahan yang terus menerus dilaksanakan untuk menuju keadaan yang lebih baik berdasarkan norma-norma yang berlaku di masyarakat. dapat di artikan juga bahwa pembangunan merupakan proses dimana antara sistem sosial yang satu dengan yang lainnya saling bertalian, Negara satu dengan Negara yang lain. Namun secara umum ada suatu kesepakatan bahwa pembangunan merupa kan proses untuk melakukan perubahan (Riyadi dan Deddy Supriyadi Bratakusumah, 2005: 26). Menurut Siagian (1994), memberikan pengertian tentang pembangu nan sebagai "Suatu usaha atau rangkaian usaha pertumbuhan dan perubahan yang berencana dan dilakukan secara sadar oleh suatu bangsa, negara dan pemerintah, menuju modernitas dalam rangka pembinaan bangsa (nation building)".

Disamping itu juga, Pariwisata merupakan sebuah industri jasa yang perkembangannya kian pesat setiap tahun nya. Di Indonesia sektor pariwisata dikembangkan sebagai sektor yang

DOI: 10.25077/jantro.v20.n1.p45-55.2018

JANTRO ISSN: 2355-5963 (Online)

under Lisensi Creative Commons Atribusi-BerbagiSerupa 4.0 Internasional menjanjikan mendatangkan pendapatan besar bagi negara terlebih di daerah-daerah yang memiliki sumber daya alam maupun sumber daya budaya yang melimpah. Ber bagai potensi digali untuk menarik minat para wisatawan untuk datang berkunjung sehingga diharapkan mampu meningkatkan kesejahteraan masyarakat. Kepulauan Riau sebagai salah satu destinasi pariwisata di Indonesia yang memiliki keunikan wisata yang khas. Keunikan dan potensi pariwisata yang ada di Kepulauan Riau yang dikembangkan sebagai salah satu destinasi pariwisata berbasiskan pada budaya serta ditunjang oleh keindahan alam yang sangat menarik. Munculnya wisata bahari sebagai tempat yang paling diminati berdampak kepada kepariwisataan di daerah Kepulauan Riau. Banyak perubahan terjadi akibat dari perkembangan pariwisata. Namun yang paling menarik perhatian adalah tingginya tingkat pembangunan usaha akomodasi pariwisata dengan jumlah lahan yang sangat terbatas.

Keterbatasan tersebut tidak serta merta menghentikan pembangunan bahkan mengakibatkan semakin tingginya tingkat 
alih fungsi yang mengancam eksistensi ruang terbuka hijau yang juga berimbas ke daerah lain sebagai mana yang terjadi di Desa Teluk Bakau Kecamatan Gunung Kijang. Warga Desa Teluk Bakau yang berprofesi sebagai nelayan semakin jauh untuk kepantai. Para warga yang berprofesi sebagai nelayan harus menempuh jarak sejauh 5-10 $\mathrm{Km}$ untuk menuju tempat berlabuh sampan atau pompong yang menjadi alat transportasi mereka untuk mencari atau membawa hasil tangkapan ikan. Hal ini sangat dirasakan oleh warga desa Teluk Bakau, apalagi pembangunan pariwisata yang mengeksploitasi alih fungsi lahan pesisir semakin gencar dilakukan oleh pihak pengembang pariwisata. Warga Desa Teluk Bakau semakin khawatir dengan keadaan ini. masyarakat beranggapan bahwa untuk kedepannya mereka tidak bisa lagi menjalankan rutinitas mereka sebagai nelayan, karena sepanjang daerah pesisir pantai sudah dipagar oleh pengembang pariwisata, sehingga masyarakat kesulitan mengakses untuk menuju perahu di pinggiran pantai, pemerintah daerah juga harus memperhatikan Peraturan Presiden Nomor 51 Tahun 2016 tentang Batas Sempadan Pantai, di mana dalam aturan tersebut yang mengarahkan pada pembangunan di wilayah pantai dan harus mengacu kembali RTRW yang berlaku di masing-masing kabupaten/kota.

Disamping itu juga, minimnya sumber daya manusia yang ada khususnya di Desa Teluk Bakau Kecamatan Gunung Kijang, yaitu sebagian besar penduduknya adalah masyarakat yang bermata pencaharian sebagai nelayan $62 \%$, pedagang $19 \%$, petani $13 \%$ dan pegawai negeri sipil $4,6 \%$, disamping itu juga tingkat pendidikan masyarakat tergolong rendah yaitu tidak tamat sekolah dasar $68 \%$, tamat sekolah dasar $18 \%$, tamatan sekolah menengah pertama $11 \%$ dan tamat sekolah menengah umum $9 \%$. dari data diatas dapat di lihat bahwa, secara umum masyarakat belum mampu bersaing dalam sektor pariwisata baik dalam skala kecil, menengah, maupun besar. Jika hal ini dibiarkan bukan tidak mungkin pariwisata yang awalnya diharapkan mampu untuk meningkatkan kesejahteraan masyarakat justru akan mengancam kesejahteraan masyarakat itu sendiri. Secara tangible (wujud) dampak dari kegiatan pariwisata di Desa Teluk Bakau memberikan bukti bahwa kegiatan pariwisata saat ini hanya berorientasi kepada kuantitas dan pembangunan setinggi-tingginya. Tercermin apa yang terjadi saat ini, kegiatan pariwisata mulai memberikan dampak terhadap konvensi lahan tepi pantai dalam mencari sarana akomodasi yang semakin pesat setiap tahunnya.

Seiring perubahan tata guna lahan di Desa Teluk Bakau, industri pariwisata memberikan dampak secara intangible (tak berwujud) bagi kehidupan sosial-budaya masyarakat. Namun untuk menilai dampak pariwisata secara intangible (tak berwujud) yang berkaitan dengan kehidupan masyarakat tidak lah mudah. Ada banyak faktor kontaminasi yang ikut berperan didalam mempengaruhi perubahan yang terjadi. Di satu sisi Dinas Pariwisata Kabupaten Bintan sejauh ini kurang berperan aktif dalam mengawasi pembangu nan yang dilakukan oleh pengembang pariwisata dalam menegakkan peraturan terkait tata-guna lahan dengan menyertakan kearifan lokal yang ada di Desa Teluk Bakau. Selanjutnya, usaha yang dilakukan oleh pihak Dinas Pariwisata dalam memberikan pemahaman terhadap masyara kat desa Teluk Bakau, untuk menjaga kelestarian lingkungan sosial-budaya mereka juga tidak tampak sehingga mengancam kehidupan sosial-budaya masyarakat itu sendiri.

\section{B. KONSEP TEORITIS \\ a. Pengertian Dampak}

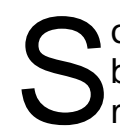
oerjono Soekanto (2006) menjelaskan bahwa, secara etimologis dampak memiliki pengertian pelanggaran, tubrukan, atau benturan, sedangkan pendekatan secara sosiologis dapat diarti kan sebagai penggunaan konsep dasar untuk menelaah sebuah gejala sosial dalam artian dampak sosial merupakan sebuah efek dari fenomena sosial yang terjadi dalam kehidupan masyarakat.

Soerjono Soekanto juga menambahkan bahwa, dampak sosial memiliki dua sifat 
yaitu bersifat positif dan bersifat negatif, atau yang sering kita sebut sebagai manifestasi dan latency.. Manifestasi mempunyai sebuah kecenderungan hara pan yang diinginkan dari suatu proses sosial yang terjadi sementara itu latency merupakan bentuk yang tidak diharapkan, tapi secara alamiah selalu menyertai atau muncul.

Sementara itu, Menurut Faizun (2009) dampak dari pariwisata adalah perubahan yang terjadi terhadap masyarakat sebagai komponen dalam lingkungan hidup sebelum ada kegiatan pariwisata dan setelah ada kegiatan pariwisata. Begitu juga menurut Pitana dan Gayatri (2005) dampak pariwi ata terhadap masyarakat dan daerah tujuan wisata mencakup: dampak terhadap sosialekonomi, dampak terhadap sosial-budaya, dan dampak terhadap lingkungan.

\section{b. Pengertian Pariwisata}

John Urry (1990) mengatakan bahwa pariwisata adalah aktivitas bersantai waktu luang yang dilakukan seseorang bebas dari pekerjaan. sementara itu menurut Inskeep (1991) mengatakan bahwa, di berbagai macam literatur dimuat berbagai macam komponen wisata. namun ada beberapa komponen wisata yang selalu ada dan merupakan komponen dasar dari wisata salah satunya adalah akomodasi. Akomodasi yang dimaksud disini adalah berbagai macam hotel dan berbagai jenis fasilitas lain yang berhubungan dengan pelayanan untuk para wisatawan yang berniat untuk bermalam selama perjalanan wisata yang mereka lakukan.Jadi yang dimaksud akomodasi pariwisata dalam penelitian ini adalah berbagai macam fasilitas yang berhubungan dengan pelayanan untuk menunjang kegiatan wisatawan saat berlibur disuatu destinasi yang bisa berupa hotel maupun vila.

\section{c. Pengertian Sosial-Kebudayaan}

Menurut Koentjaraningrat (1981), budaya dapat diarti sebagai keseluruhan gagasan dan karya manusia yang harus di biasakan dengan belajar serta keseluruhan dari hasil budi pekerti. Budaya juga bisa diwariskan melalui kontak sosial atau dengan kata lain interaksi antar kelompok masyarakat. Budaya juga merupakan kesatuan proses kegiatan yang memang secara langsung atau pun tidak langsung bertahan sebagai sebuah warisan kepada generasi selanjutnya karena dilakukan berulang-ulang kali.

Dalam penelitian ini, pengertian sosial budaya memiliki pertalian yang tidak bias di pisahkan. begitu juga dalam melihat dampak pariwisata terhadap sosial-budaya. Mathie son dan wall dalam Pitana dan Gayatri (2005) mengatakan jika tidak ada perbeadaan yang jelas antara gejala sosial dan budaya, sehingga para ahli mengga bungkan dampak sosial dan dampak budaya ke dalam satu judul yaitu dampak sosial-budaya.

\section{d. Pengertian Perubahan Sosial}

Burker (2003) mengatakan istilah perubahan sosial dipandang sebagai istilah yang taksa (ambigius). Kadangkala istilah ini digunakan dalam pengertian yang sempit, yang mengacu kepada perubahanperubahan struktur sosial, tapi juga kadangkadang digunakan pula dalam pengertian yang sangat luas yang mencakup organisasi politik, perekonomian dan kebudayaan. Di dalam bukunya, Burker menyebutkan teori perubahan sosial dari Spencer merupakan model yang menekankan pada evolusi sosial, dengan kata lain perubahan sosial yang berlangsung secara perlahan-lahan dan komulatif (evolusi) dan masyarakat berubah dari tingkat peradaban sederhana ke tingkat peradaban yang lebih komplek dan perubahan tersebut tidak selalu mengarah kearah yang lebih baik namun perubahan bisa mengarah pada kehancuran.

Perubahan sosial dapat dipengaruhi oleh faktor dari dalam dan luar masyarakat itu sendiri. Adapun faktor yang berasal dari luar antara lain menurut Elly dan Usaman (2010) yaitu sebab-sebab yang berasal dari lingkungan alam fisik yang ada disekitar manusia dan pengaruh kebudayaan masyarakat lain. Dalam penelitian ini menggunakan teori evolusi dari Spencer yaitu dampak industri pariwisata terhadap kehidupan sosial masyarakat terjadi secara 
perlahan-lahan dilihat dari perkembangan nya dan kegiatan industri pariwisata adalah faktor luar yang mempengaruhi perubahan yang terjadi di Desa Teluk Bakau, Kecamatan Gunung Kijang, Kabupaten Bintan. Sementara itu faktor dari dalam yang mempengaruhi masyarakat adalah terjadi nya kecemburuan sosial yang mengakibat kan konflik antara masyarakat tempatan dengan pengembang pariwisata sebagai mana yang terjadi di desa teluk bakau. karena komunikasi antara pengembang pariwisata dengan masyarakat tidak berjalan sebagai mana mestinya.

\section{HASIL TEMUAN DAN PEMBAHASAN}

1. Dampak Pembangunan Indus tri Pariwisata Terhadap Alih Fungsi Lahan Secara Tangible (wujud).

$\mathrm{D}$ ampak pariwisata di berbagai daerah di Kepulauan Riau mulai mengancam dan tidak bisa dielakan lagi. Seiring dengan gencarnya perkembangan pariwi sata membawa pengaruh dan efek negatif terutama bagi kehidupan sosial-budaya pada masyarakat. kegiatan pariwisata yang erat kaitanya dengan proses sosial secara perlahan mulai mempengaruhi semua elemen didalam pariwisata termasuk masyarakat. Soerjono Soekanto (2005) mengenai analisisnya yang sering kita ketahui adalah manifestasi dan latency. Suatu proses sosial mempuyai sebuah kecenderungan harapan yang diinginkan dari suatu proses sosial yang terjadi yang disebut manifestasi namun ada bentukbentuk yang tidak diharapkan dalam proses sosial tersebut, tapi secara alamiah selalu menyertai atau muncul yang disebut se dangkan latency. artinya bahwa, dalam sektor pariwisata diharapkan mampu sebagai mesin pengerak ekonomi bagi pembangunan ekonomi di Desa Teluk Bintan yang harus mampu memberikan sumbangsih dalam mensejahterakan masyarakat tepatan yaitu dengan harapan mampu memberikan kesempatan kepada seluruh masyarakat disekitar pariwisata yang berada di Desa teluk Bakau untuk berusaha dan bekerja sehingga mempu memberi andil yang cukup besar dalam meningkatkan perekonomian masyarakat setempat serta mengentaskan kemiskinan.

Proses kegiatan pariwisata yang ada di Desa Teluk Bakau serupa dengan apa yang disebut sebagai manifestasi dan latency oleh Soerjono. Kegiatan pariwisata yang berlangsung di Desa Teluk Bakau memunculkan harapan bagi masyarakat untuk mendapatkan keuntungan yang sebesar-besarnya dari kegiatan tersebut. Harapan untuk mendapatkan keuntungan dari kegiatan pariwisata kemudian diwujudkan oleh masyarakat melalui penyediaan layanan-layanan pariwisata untuk melengkapi kebutuh wisatwan yang berkunjung seperti pembangunan sarana akomodasi pariwisata seperti hotel, villa, dan guest house. Dari sini kemudian masyarakat Desa Teluk Bakau memperoleh keuntungan terutama finansial yang sangat besar.

Munculnya wisata bahari yang merupakan pariwisata di wilayah kawasan pesisir yang terletak di sepanjang garis pantai yang merupakan sebagai tempat paling diminati berdampak kepada kepariwisataan di daerah Kepulauan Riau. Banyak perubahan terjadi akibat dari perkembangan pariwisata. Namun yang paling menarik perhatian adalah tingginya tingkat pembangunan usaha akomodasi pariwisata dengan jumlah lahan yang sangat terbatas. Keterbatasan tersebut tidak serta merta menghentikan pembangunan bahkan mengakibatkan semakin tingginya tingkat alih fungsi yang mengancam eksistensi ruang terbuka hijau yang juga berimbas ke daerah lain seperti di Desa Teluk Bakau, Kecamatan Gunung Kijang. Warga Desa Teluk Bakau yang berprofesi sebagai nelayan semakin jauh untuk kepantai. Para warga yang berprofesi sebagai nelayan harus menempuh jarak sejauh 5-10 Km untuk menuju tempat berlabuh sampan atau pompong yang menjadi alat transportasi mereka untuk mencari atau membawa hasil tangkapan ikan.

Hal ini sangat dirasakan oleh warga desa Teluk Bakau, apalagi pembangunan pariwisata yang mengeksploitasikan alih fungsi lahan pesisir semakin gencar dilakukan oleh pihak pengembang pariwisata. Warga Desa Teluk Bakau semakin khawatir dengan keadaan 
pengembangan pariwisata yang sedang berjalan. Mereka beranggapan bahwa untuk kedepannya mereka tidak bisa lagi menjalankan rutinitas mereka sebagai nelayan, karena sepanjang daerah pesisir pantai sudah dipagar oleh pihak pengembang pariwisata. disamping itu juga, minimnya sumber daya manusia yang ada khususnya di Desa Teluk Bakau, Kecamatan Gunung Kijang, masih belum mampu bersaing dalam sektor pariwisata baik dalam skala kecil, menengah, maupun besar. Jika hal ini dibiarkan bukan tidak mungkin pariwisata yang awalnya diharapkan mampu untuk meningkatkan kesejahteraan masyarakat justru akan mengancam kesejahteraan masyarakat itu sendiri.

\section{a. Alih Fungsi Lahan di Desa Teluk Bakau}

Secara tangible dampak dari kegiatan pariwisata yang terjadi di Desa Teluk Bakau memberikan bukti bahwa kegiatan pariwisata saat ini hanya berorientasi kepada kuantitas dan pembangunan setingg-tingginya. Tercermin dari apa yang terjadi saat ini, kegiatan pariwisata mulai memberikan dampak terhadap konvensi lahan pinggir pantai menjadi sarana akomodasi yang semakin pesat setiap tahunnya, sehingga sekitar $80 \%$ lahan pinggir pantai sudah dikuasai oleh pihak pengembang pariwisata. Seperti pernyataan bapak ZA salah satu warga RW 02/ RT 03 Desa Teluk Bakau dari hasil wawancara yang dilakukan oleh peneliti yaitu sebagai berikut:

"Kalau masalah lahan pinggir pantai, saat ini masih ada tetapi jumlahnya tidak seluas dulu. Sekarang sudah banyak yang berubah lahan pinggir pantai yang tersisa masih sekitar 30\% yang disebabkan pertumbuhan vila dan guest house yang dibangun diatas lahan pinggir pantai, sehingga menyulitkan kami untuk menambat bot atau sampan untuk melaut karna lahan pinggir pantai di Desa Teluk Bakau ini banyak yang sudah dipagar untuk dibangun tempat wisata. Perkembangan pariwisata yang ada di Desa Teluk Bakau sangat mempengaruhi pertumbuhan villa-villa ini. Alih fingsi lahan juga dipicu oleh adanya Agro Resort sejak tahun 2002, jadi semakin banyak bule yang datang ke sini."(14/11/2017)

Jika dilihat dari pernyataan tersebut, tersirat bahwa pertumbuhan villa dan guest house tersebut semakin mengancam eksistensi nelayan yang ada di Desa Teluk Bakau. Dengan demikian, Desa Teluk Bakau yang masuk ke dalam kawasan Kabupaten Bintan sebagai wilayah wisata bisa dipertanyakan. Masih pantaskah kawasan Kepulauan Riau khususnya Desa Teluk Bakau ini ditetapkan sebagai kawasan wisata di tengah pelanggaran kebijakan mempertahankan wilayah Kabupaten Bintan sebagai kawasan wisata dalam arti luas yang di maksud dengan kawasan wisata adalah kawasan yang di bangun sebagai tempat wisata dan disediakan untuk wisatawan melakukan aktifitas serta pembangunan-pembanguna yang sudah di peruntukan sebagai kawwasan wisata dan mencegah alih fungsi lahan pinggir pantai dengan meningkatkan produktivitas dan pendapatan nelayan mengalami banyak pelangaran di berbagai sisi.

Pengaruh-pengaruh pariwisata secara perlahan berdampak negatif terhadap kelestarian alam lingkungan di Desa Teluk Bakau. Dampak pembangunan pariwisata dapat kita lihat secara langsung seperti yang terjadi di Desa Teluk Bakau ini. Wilayah ini merupakan wilayah yang merasakan langsung pengaruh dari perkembangan pembangunan pariwisata yang berdampak terhadap perubahan fisik lahan di Desa Teluk Bakau.

Secara tangible pertumbuhan jasa penginapan untuk wisatawan di Desa Teluk Bakau seperti hotel dan villa ternyata banyak berdampak negatif. Dan jika dikaitkan dengan pendekatan manifestasi dan latency, fenomena ini adalah latency atau sebuah bentuk yang tidak diharapkan dari proses perkembangan pariwisata yang secara alamiah selalu menyertai atau muncul. Adapun dampak negatif tersebut adalah tata guna lahan pinggir pantai yang terancam eksistensinya karena pembangu

DOI: 10.25077/jantro.v20.n1.p45-55.2018

JANTRO ISSN: 2355-5963 (Online)

under Lisensi Creative Commons Atribusi-BerbagiSerupa 4.0 Internasional 
nan hotel dan villa diatas lahan pinggir pantai yang dikelola masyarakat sebelum nya. Secara tangible dampak dari kegiatan pariwisata di Desa Teluk Bakau memberikan bukti bahwa kegiatan pariwisata saat ini hanya berorientasi kepada kuantitas dan pembangunan setinggi-tingginya. Tercermin apa yang terjadi saat ini, kegiatan pariwisata mulai memberikan dampak terhadap konvensi lahan tepi pantai dalam mencari sarana akomodasi yang semakin pesat setiap tahunnya.

\section{b. Kehidupan Sosial Masyarakat}

Dampak pariwisata terhadap tata-guna lahan seperti beralihnya fungsi lahan pertanian menjadi sarana akomodasi pariwisata memberikan dampak sosial bagi masyarakat Desa Teluk Bakau yang dapat dilihat dari mobilitas penduduk dan terhadap mata pencaharian (perubahan pekerjaan). Semakin banyaknya jumlah penduduk memberikan dampak terhadap kehidupan sosial warga masyarakat. Bertambahnya jumlah penduduk yang tinggal di Desa Teluk Bakau berdampak terhadap tingkat kriminalitas yang terjadi.

Ada beberapa kasus pernah terjadi di Desa Teluk Bakau seperti pencurian di tempat penginapan wisatawan. Bahkan tingkat kriminalitas berupa pencurian semakin marak terjadi. Pada tahun 2012 terjadi dua kali pencurian yang menyasa pada salah satu rumah warga. $\mathrm{Hal}$ ini dipandang sebagai hal yang sangat mengkawatirkan karena semakin pesatnya perkembangan pariwisata dan jumlah penduduk tidak diimbangi dengan tingkat keamanan yang ada di Desa Teluk Bakau.

Tidak saja masalah keamanan yang menjadi masalah di Desa Teluk Bakau. Masalah kebersihan juga sedang dihadapi oleh warga desa. Semakin banyaknya jumlah wisata mengakibatkat jumlah sampah yang diproduksi semakin banyak. Sampah yang muncul ini ternyata tidak diimbangi oleh tempat pembuangan yang memadai. Di Desa Teluk Bakau sendiri tidak ada tempat pembuangan akhir untuk sampah-sampah yang diproduksi. Sampah yang dihasilkan biasanya dibuang ditempat pembuangan sementara yang berada tidak jauh dari perumahan warga.

Dari sisi mata pencaharian, kegiatan pariwisata memberikan peluang yang besar bagi masyarakatnya untuk bekerja dan senantiasa terbuka baik yang bersifat formal maupun informal. Dari sisi informal masyarakat diberikan keuntungan dari kegiatan pariwisata yang cukup besar. Pariwisata yang berkembang di Desa Teluk Bakau membuka peluang bagi masyarakat untuk membuka usaha seperti membuka peluang masyarakat untuk mendirikan kioskios dan warung makanan. Dibidang formal masyarakat diberikan keuntungan sebagai tuan rumah untuk bekerja di hotel maupun vila yang ada di Desa Teluk Bakau. Munculnya pembangunan pariwisata pada akhirnya mengakibatkan semakin banyak warga Desa Teluk Bakau yang bekerja disektor pariwisata dan mulai meninggalkan pekerjaan tradisional mereka yang mereka kerjakan sebelum adanya pariwisata seperti bekerja sebagai petani, dan nelayan.

Meskipun lapangan pekerjaan yang di sediakan oleh pihak pariwisata untuk masyarakat Desa Teluk Bakau tidak cukup membantu terutama bagi masyarakat yang berprofesi sebagai nelayan, dengan alasan penghasilan yang mereka dapatkan dari hasil melaut lebih besar jika dibandingkan dengan penghasilan sebagai karyawan pariwisata setiap bulannya. Hal ini seharusnya menjadi perhatian khusus bagi pemerintah atau dinas terkait. Namun, sayangnya pemerintah atau dinas terkait kurang berperan aktif dalam memperhatikan pemasalahan-permasalahan terkait adanya alih fungsi lahan yang dilakukan oleh pihak pariwisata.

Disamping itu, pentingnya pengemba ngan ekonomi kreatif sangat membantu perekonomian masyarakat Desa Teluk Bakau. Ekonomi kreatif dan sektor wisata merupakan dua hal yang saling berpengaruh dan dapat saling bersinergi jika dikelola dengan baik (Ooi, 2006). Konsep kegiatan wisata dapat didefinisikan dengan tiga faktor, yaitu harus ada something to see,something to do, dan something to buy (Yoeti, 1985). Something to see terkait dengan atraksi di daerah tujuan wisata, something to do terkait dengan aktivitas 
wisatawan di daerah wisata, sementara something to buy terkait dengan souvenir khas yang dibeli di daerah wisata sebagai memorabilia pribadi wisatawan. Dalam tiga komponen tersebut, ekonomi kreatif dapat masuk melalui something to buy dengan menciptakan produk-produk inovatif khas daerah.

\section{c. Kebudayaan masyarakat}

Seperti umumnya desa-desa yang ada di Kabupaten Bintan, Desa Teluk Bakau merupakan desa yang memiliki kebudayaan yang hampir sama dengan daerah lainya. Kegiatan ritual keagamaan, pertunjukan, kelompok yang dimiliki hampir tidak ada perbedaan dengan daerah lain. Kegiatan ritual keagamaan seperti mandi sapar, yang di maksud dengan mandi safar di sini adalah aktifitas masyarakat yang di lakukan secara turun menurun setiap bulan safar sebagai tolak bala adalah sebagai simbol membersihkan diri dengan harapan agar bersih dan terhindar dari hal-ha yang tidak baik. misalnya biasanya dilakukan oleh masyarakat Desa Teluk Bakau di bulan Sapar, lalu masyarakat beramai-ramai mandi di pantai, namun semenjak pembangunan pariwisata ritual itu tidak diadakan lagi karena adanya alih fungsi lahan pinggir pantai. Bagi generasi penerus hal ini sangatlah memperihatinkan, budaya yang pernah menjadi bagian dari kehidupan masyarakat Desa Teluk Bakau.k kini tidak bisa lagi diwariskan kepada generasi penerusnya.

Dampak sosial-budaya pariwisata terha dap kehidupan masyarakat local merupakan suatu pekerjaan yang sangat sulit, terutama dari segi metodologisnya. Salah satu kendala yang hamper tidak dapat diatasi adalah benyaknya faktor kontaminasi yang ikut berperan di dalam mempengaruhi perubahan yang terjadi. Melihat dampak sosial-budaya pariwisata terhadap masya rakat setempat, masyarakat tidak dapat dipandang sebagai suatu yang internally totally integrated entity, melainkan harus di lihat segmen yang ada atau melihat berbagai interest groups, karena dampak terhadap kelompok sosial yang satu dengan yang lainnya belum tentu sama.

\section{Dampak Pembangunan Industri Pariwisata Terhadap Alih Fungsi Lahan Secara Intangibel (tak ber wujud)}

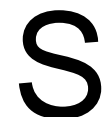

eiring perubahan tata guna lahan di Desa Teluk Bakau pariwisata memberikan dampak secara intangi ble bagi kehidupan sosial-budaya masyarakat. Namun untuk menilai dampak pariwisata secara intangible yang berkaitan dengan kehidupan masyarakat lokal tidaklah mudah. Pitana dan Gayatri (2005) ada banyak faktor kontaminasi yang ikut berperan di dalam mempengaruhi peruba han yang terjadi.

Dalam kaitanya dengan dampak pembangunan pariwisata terhadap kehidupan masyarakat,harus dilihat dari banyak faktor yang mempengaruhi perubahan tersebut, seperti pendidikan, media masa, dan komunikasi yang menjadi wahana perubahan sosial tersebut. Meskipun ada banyak faktor yang mempengaruhi perubahan yang terjadi di dalam masyarakat, tetap saja pengaruh pariwisata sangat kuat kaitannya dengan dampak pariwisata yang terjadi di Desa Teluk Bakau. Dampak pariwisata secara intangible ini sepintas nampaknya sederhana. Akan tetapi konsekuensi secara jangka panjang akan sangat fundamental, seperti hilangnya jati diri dari masyarakat.

Ada banyak faktor kontaminasi yang ikut berperan didalam mempengaruhi perubahan yang terjadi. Drs. B. simandjuntak, S.H. (1992: 120) mengatakan "masyarakat dalam interaksinya merupakan suatu sistem dimana nilai-nilai sosial yang melandasinya merupakan suatu konfigurasi yang terjalin satu sama lain. Perubahan sosial yang cepat dapat menimbulkan ketidakseimbangan diantara berbagai nilai sosial, sektor kehidupan masyarakat atau menimbulkan perkembangan yang tidak sejalan dalam berbagai sektor kehidupan". artinya masyarakat didalam berinteraksi harus berlandaskan nilai-nilai yang terjalin bersama masyarakat yang satu dengan yang lainnya, sehingga meminimalisir terjadinya kontaminasi akibat perubahan sosial yang terjadi. 
Untuk menghadapi permasalahan di atas diperlukan perencanaan sosial yang kompherensif untuk menjaga agar situasi kembali kondusif. St. Vembriarto (1977:13) perencanaan atau rencana (Planning) adalah "penerapan secara sistematik dari pengetahuan untuk mengontrol dan mengarahkan arah kecenderungan peruba han menuju kepada tujuan yang ditetapkan". Prof. Dr J.W. Schorl (1980:295) mengatakan "perencanaan sosial ini meliputi penetapan rencana-rencana untuk kegiatan yang akan datang yang berhubungan dengan lembagalembaga dan sumber-sumber sosial". dalam pengembangan pariwisata harus melakukan perencanaan sosial untuk aktivitas yang akan datang atau yang kita kenal dengan istilah pembangunan pariwisata yang berkelanjutan.

\section{a. Pergeseran Nilai dan Solidaritas Masyarakat}

Pitana dan Gayarti (2005) mengatakan kegiatan industri pariwisata disuatu daerah dikatakan telah mengahncurkan sifat-sifat kebersamaan didalam masyarakat dan kemudian digantikan oleh sifat indivi dualisme pragmatis. Sebelum masuknya industri pariwisata mayarakat yang sebagaian besar belum bergelut dalam kegiatan industri pariwisata memiliki tingkat partisipasi yang tinggi didalam berorganisasi dan memiliki waktu luang yang cukup untuk berorganisasi. Seiring pertumbuhan pariwisata, kesibukan semakin bertambah, dan sering mengorbankan kegiatan di dalam masyarakat.

Dengan bergabungnya masyarakat di dalam dunia industri pariwisata, mampu melumpuhkan partisipasi masyarakat terhadap upacara keagamaan yang dianggap sakral bagi masyarakat tersebut, salah satu contohnya adalah sholat Idul Fitri. Dengan kesibukan dan tuntutan kewajiban yang dimiliki oleh masyarakat yang bergabung didalam dunia industri pariwisata memaksa mereka untuk tidak mengikuti upacara keagamaan yang bagi masyarakat umat muslim pada umumnya sangatlah sakral, khususnya bagi sebagian masyarakat Desa Teluk Bakau yang bergabung di dalam kegiatan industri pariwisata yang kebetulan mayoritasnya adalah muslim.

Secara intangible terlihat ada sebuah pergerakan dari masyarakat yang kini cenderung berorientasi kearah keuntungan secara finansial atau profit oriented. Industri pariwisata dipandang sebagai kegiatan yang menguntungkan dan mampu mendatangkan pendapatan yang besar. Sehingga banyak dari mereka yang memutuskan untuk mengeluti dunia industri pariwisata meski ada banyak hal yang harus dikorbankan termasuk waktu luang. Terbatasnya waktu luang akhirnya membuat seseorang harus memilih. Disinilah sifat individualisme mulai muncul di dalam diri masyarakat. Dampak nya, seseorang lebih memilih sesuatu yang dirasa lebih menguntungkan untuk dirinya dan mengabaikan kepentingan di masyara kat seperti partisipasinya didalam berorganisasi.

Pandangan-pandangan seperti ini mulai muncul ketika industri pariwisata mulai berkembang. Perkembangan industri pariwisata banyak memberikan pilihanpilihan yang memaksa beberapa pihak untuk bertindak diluar jalur yang semestinya mereka lakukan. Budaya hidup yang menempatkan kepentingan pribadi dibawah kepentingan umum secara perlahan telah berubah digantikan pandangan baru yang tentunya jika di kaitakn dengan budaya masyarakat Melayu akan bertolak belakang.

Menurut Isjoni (2007: 30), budaya Melayu merupakan konsep yang menjelas kan satu keseluruhan cara hidup Melayu di alam Melayu. Orang Melayu di mana juga berada akan menyebut fenomena budaya mereka sebagai "ini adat kaum" masyarakat Melayu mengatur kehidupan mereka dengan adat agar setiap anggota adat hidup beradat, seperti adat alam, hukum adat, adat beraja, adat bernegeri, adat berkampung, adat memerintah, adat berlakibini, adat bercakap, dan sebagainya.

Secara kasat mata industri pariwisata mempengaruhi sifat-sifat individu dalam mengambil keputusan. Terabaikannya anggapan bahwa kita harus mementingkan kepentingan umum sebelum kepentingan pribadi memunculkan sifat-sifat individualis didalam pengambilan keputusan tersebut. Sifat "Gotong Royong" atau bermasyarakat, 
secara intangible mulai sedikit berubah mengarah kesifat individualis yang dalam kehidupan bermasyarakat bisa berdampak negative seperti mulai munculnya stigma negative yang bisa memunculkan konflik.

\section{Peran Pemerintah Dalam Pengem bangan Industri Pariwisata di Desa Teluk Bakau}

Sebagai industri perdagangan jasa, kegiatan pariwisata tidak terlepas dari peran serta pemerintah baik pemerintah pusat maupun pemerintahdaerah. Pemerintah bertanggung jawab atas empat hal utama yaitu; perencanaan (planning) daerah atau kawasan industri pariwisata, pembangunan (development) fasilitas utama dan pendu kung pariwisata, pengeluaran kebija kan (policy) pariwisata, dan pembuatan dan penegakan peraturan (regulation).

Namun, kenyataan di lapangan menunjukkan bahwa pengembangan Desa Wisata belum berpihak kepada masyarakat Desa Teluk Bakau. Karl Marx (1883) dengan konsep economic mode of production, yaitu menghasilkan kelas yang mengeksplotasi dan kelas yang tereksplotasi, bahwa masyarakat ada dalam situasi stabil dan tidak berubah sebaliknya masyarakat selalu dilihat dalam kondisi tidak seimbang atau tidak adil, karena terdapat kelompokkelompok yang memagang kekuasaan, bias di lihat secara fakta bahwa, lahan pinggir pantai merupakan aset pariwisata yang dijual untuk kepuasan wisatawan. Ada kemiripan apa yang di katakan oleh Marx dan Engels menyebutkan bahwa, para penguasa sebagai kaum bourgeoisie, dan masyarakat sebagai kaum proletar yang tertindas dan pada akhirnya akan menyebabkan perlawanan atas dasar ketidak adilan. Namun, pengembangan desa wisata tidak berpihak kepada kehidupan Masyarakat. Kehidupan Sosialekonomi masyarakat Desa Teluk Bakau tidak mengalami perubahan sementara investor meraup keuntungan besar dari aktivitas pariwisata ini. Padahal, jika tidak ada lahan pinggir pantai industri pariwisata di Desa Teluk bakau tidak akan berkembang.

DOI: 10.25077/jantro.v20.n1.p45-55.2018

JANTRO ISSN: 2355-5963 (Online)

under Lisensi Creative Commons Atribusi-BerbagiSerupa 4.0 Internasional
Perlunya peran aktif dari Dinas Pariwisata Kabupaten Bintan dalam mengawasi pembangunan yang dilakukan oleh pihak industri pariwisata dalam menegakkan dan mempertegas peraturan terkait tata-guna lahan dengan menyertakan kearifan lokal yang ada di Desa Teluk Bakau. Selanjutnya, usaha yang dilakukan oleh pihak Dinas Pariwisata dalam memberikan pemahaman terhadap masya rakat desa Teluk Bakau, untuk menjaga kelestarian lingkungan sosial-budaya masyarakat juga tidak tampak sehingga mengancam kehidupan sosial-budaya masyarakat itu sendiri.

Masuknya pemilik modal dalam pengembangan desa wisata membangun area kompetisi ekonomi. Kompetisi tidak saja dalam perebutan lapangan pekerjaan juga dalam hal modal. Kelompok kapitalis lokal bersaing dengan pemodal kuat dari luar desa bahkan berasal dari luar Kepulauan Riau. Jika kondisi ini dibiarkan akan menimbulkan ketidakadilan ekonomi antara masyarakat lokal dengan pendatang. Ketidakadilan berpotensi terjadinya konflik. Oleh karena itu, memberi ruang gerak bagi tumbuhnya ekonomi kerakyatan sangat diperlukan. Jika tidak, kenyamanan kehidu pan sosial-budaya masyarakat Desa Teluk Bakau akan dipertaruhkan. Pariwisata dapat menghancurkan sendi-sendi kehidupan sosial-budaya masyarakat Desa Teluk Bakau.

\section{KESIMPULAN}

$\mathrm{B}$ erdasarkan hasil penelitian di atas, maka dapat ditarik beberapa kesimpulan bahwa Wilayah Desa Teluk Bakau merupakan salah satu destinasi wisata asing yang sangat diminati yang disebabkan oleh keindahan alam baharinya. Hal tersebut dibuktikan dengan adanya beberapa tempat wisata dan penginapan yang ada di wilayah Desa Teluk Bakau antara lain, seperti Agro Risort, White Island, Nikoi Island, Spa Villa, Gurindam Risort, Sahid Bintan Hotel, dan wisata bawah laut atau Snorkling.

Dapat kita lihat bahwa, dengan adanya pembangunan Pariwisata tersebut menunjuk kan bahwa adanya perubahan yang secara 
perlahan-lahan memberikan dampak bagi kehidupan sosial masyarakat, yang diakibatkan dengan semakin berkembang nya kegiatan industri pariwisata. yang erat kaitanya dengan proses sosial secara perlahan-lahan mulai mempengaruhi semua elemen di dalam kehidupan sosial masyarakat baik itu bersifat Tangible (wujud) dan intangible (tak Wujud).

Sejauh ini Dinas atau instansi terkait harus berperan aktif dalam melakukan pengawasan terhadap kegiatan industri pariwisata, sehingga banyak memberikan dampak negative bagi kehidupan sosial masyarakat. Contohnya pengawasan dan menegakkan peraturan terkait tata-guna lahan dengan menyertakan kearifan lokal. begitu juga dengan pola pikir masyarakat yang profit oriented (mengutamakan keuntungan) harus diubah menjadi environ ment oriented for tourism (berorientasi pada lingkungan untuk pariwisata) agar kedapan nya masyarakat lebih perduli terhadap lingkungan sosial-budaya mereka sehingga dampak negative dari pariwisata tidak mengancam kehidupan sosial-budaya ma syarakat.

\section{E. UCAPAN TERIMAKASIH}

Denulis mengucapkan terimakasih kepada pihak redaksi Jurnal Antropologi: Isu-Isu Sosial Budaya, Universitas Andalas, atas perkenannya mempublikasikan artikel ini.

\section{Daftar Pustaka}

Agus Dipayana, Nyoman Sunarta, (2015). "Dampak Pariwisata Terhadap Alih Fungsi Lahan Di Desa Tibu Beneng Kecamatan Kuta Utara Kabupaten Badung (Studi SosialBudaya)", Jurnal Destinasi Pariwisata, Vol. 3 Denpasar.

Bungin, Burhan. (2008). Metodologi Penelitian Kualitatif. Jakarta: PT Raja Grafindo Persada.

Burker, Peter. (2003). Sejarah dan Teori Sosial.Jakarta: Yayasan Obor Indonesia.

Pitiana, I. Gede dan Sayantri, Putu G. (2005). Sosiologi Pariwisata. Yogyakarta: Andi

Simanjuntak, S.B. (1992). Analisis Daya Saing dan Dampak Kebijaksanaan Pemerintah Terhadap Daya Saing Perusahaan Kepala Sawit Indonesia. Desertasi: Program Pasca Sarjana IPB. Bogor

Soekadijo, R,G. (1995). Anatomi Pariwisata: Memahami Pariwisata sebagai "Systemic Linkage". Jakarta: Gramedia.

Soekadijo, R,G. (1997). Wisata Minat Khusus. Yogyakarta: PAU Studi Sosial Universitas Gadjah Mada.

Schorl. JW. (1980). Modernisasi Pengantar Sosiologi Pembangunan Negara-Negara Sedang Berkembang.Jakarta: Gramedia, 1980.

Utomo, M., Eddy Rifai dan Abdulmutalib Thahir. (1992)..Pembangunan dan Alih Fungsi Lahan. Lampung: Universitas Lampung.

Vembriarto. St. (1977). Sosiologi Pendidikan. Yayasan Pendidikan Paramita 